\title{
Islam, the State and Turkey's Syrian Refugees: The Vaiz of Bursa
}

DOI:

10.1093/jrs/fey025

\section{Document Version}

Accepted author manuscript

Link to publication record in Manchester Research Explorer

\section{Citation for published version (APA):}

Jacoby, T., Mac Ginty, R., \& enay, B. (2019). Islam, the State and Turkey's Syrian Refugees: The Vaiz of Bursa. Journal of Refugee Studies, 32(2), 237-256. https://doi.org/10.1093/jrs/fey025

\section{Published in:}

Journal of Refugee Studies

\section{Citing this paper}

Please note that where the full-text provided on Manchester Research Explorer is the Author Accepted Manuscript or Proof version this may differ from the final Published version. If citing, it is advised that you check and use the publisher's definitive version.

\section{General rights}

Copyright and moral rights for the publications made accessible in the Research Explorer are retained by the authors and/or other copyright owners and it is a condition of accessing publications that users recognise and abide by the legal requirements associated with these rights.

\section{Takedown policy}

If you believe that this document breaches copyright please refer to the University of Manchester's Takedown Procedures [http://man.ac.uk/04Y6Bo] or contact uml.scholarlycommunications@manchester.ac.uk providing relevant details, so we can investigate your claim.

\section{OPEN ACCESS}




\title{
Islam, the State and Turkey's Syrian Refugees: The Vaiz of Bursa
}

\author{
Tim Jacoby, Roger Mac Ginty and Bülent Şenay*
}

\begin{abstract}
This study looks at the work of Turkey's network of state "preachers" in the management of Syrian refugees in Bursa, a city in the north-west of the country. Based on interviews and workshops undertaken between 2015 and 2017, it traces out how these civil servants have approached a rapidly changing social situation in which belief and organised religion continue to be highly important. It focuses on the role of Islam in the provision of basic assistance programmes, the management of local conflicts and broader efforts at ensuring long-term integration. In each of these areas, our research reveals that faith remains a significant motivational element in the Turkish state's response to the Syrian refugee crisis.
\end{abstract}

\section{Introduction}

International assistance to those affected by war has long had close ties with organised religion. Henry Dunant's 1862 book, Un Souvenir de Solferino, for instance, pointed to a need for the creation of relief societies 'both from the humane and Christian standpoint' (cited in Perna, 2006: 34). With the expansion of Western aid efforts following the Second World War, it was, as Anne-Marie Holenstein notes, missionary societies that were 'among the first institutions in the 1950s and 1960s to become partners of the newly created governmental donor agencies' (2005: 367-8). This shift in focus - from eliciting charitable support from those who largely shared their values to competing for commissions and contracts from state agencies - drove a conjoined process of professionalisation and secularisation. As a commitment to neutrality and impartiality became preconditions for funding, 'organizations with varying connections to faith traditions... generally adopted an approach and discourse that rendered it difficult to distinguish them on many criteria from secular agencies' (Ager and Ager, 2011: 457). Some, such as TearFund and CAFOD assumed acronyms that obscured their respective evangelical or Catholic roots, while others changed their names completely - the Catholic Institute for International Relations became Progressio in 2006, the Christian Children's Fund became ChildFund International in 2009 and so on.

\footnotetext{
* Tim Jacoby, Global Development Institute, University of Manchester; Roger Mac Ginty, Humanitarian and Conflict Response Institute, University of Manchester; Bülent Şenay, Illahiyat Fakültesi, Uludağ Üniversitesi. We are grateful to the British Academy for funding our fieldwork (award SG152259) and to Gülsen Sufracı and Bayram Akbulut for their research assistance.
} 
Alongside this trend, however, have been regular efforts to reappraise the role of religion in humanitarian action. A World Faiths Development Dialogue was established by the World Bank in 1998, the UK's Department for International Development doubled its funding for faith-based organisations in 2005 and the United Nations' High Commissioner for Refugees (UNHCR) assembled 400 representatives for a Dialogue on Faith and Protection in 2012 (Ager and Ager, 2015: 6-7). A growing sense has emerged that the separation of faith from reason cannot be universalised, and that such a move would significantly limit humanitarian space. As Alastair Ager observes, 'there is an increasing acceptance that the world of faith cannot be pragmatically or legitimately confined to the private sphere' (2014: 17). To do so would, after all, foreclose the possibility that 'values such as democracy, freedom, equality, inclusion and justice may not necessarily be best pursued within an immanent secular framework' (Mavelli and Petito, 2012: 931).

Nonetheless, and notwithstanding recent claims that we are entering a "post-secular" age (Wilson and Mavelli, 2017), religiously orientated humanitarian work remains 'rarely well documented and [are] generally poorly understood by national and international actors' (Ager and Ager, 2017: 47). Specifically, 'there is still little serious consideration or understanding of the potential contribution that faith discourses and values may make to practically improving protection and provision for forced migrants' (Kidwai, 2017: 178, emphases in original). The view that revealed scripture is 'beyond the legitimate scope of humanitarian[ism]' and that religious beliefs are merely 'effects of more "basic" units of reality' remains dominant (Ager and Ager, 2015: 17). This has tended to subsume the ideational content of faith-based organisations' approach beneath narratives of identity, improved access and localisation. A recent 19-point joint statement from the UNHCR and the Organisation of Islamic Cooperation, for example, makes only one brief reference to religious teachings, while an 84-page special edition of Forced Migration Review entitled "Faith and Responses to Displacement" from 2014 contains just four mentions of God. Given that 'local faith communities are often at the forefront of humanitarian engagement with displaced populations', this represents a significant lacuna (Kidwai, 2017: 178). As Alastair Ager continues, the 'secular script' that structures international engagement with refugees has little social resonance in much of the non-Western world (where polls regularly record religious affiliation rates of more than 90 per cent), thereby 'creating a disconnect with many local resources relevant for their recovery' (2014: 17).

Our study focuses on these local resources. It seeks to cover the acutely under-researched area of state-sponsored religious humanitarian providers. There are practical arguments in favour of the Turkish government's use of its religious resources to disburse assistance to refugees: they are close to the ground, are already in place, know how the system works, may be culturally close to the recipient population, and tend to take a joined-up approach to needs. But the case study also raises questions about the role of the state in areas of society that might be regarded as civil in other contexts, as well as additional issues about the meanings of humanitarianism and its place within the responsibilities of the state and civil society. Questions about religiousstate relations in particular are useful in that they provoke further inquiries about the assumed universalism of western models of humanitarianism. 
Specifically, we focus on the religiously derived motives, values and policies of Turkey's Diyanet Işsleri Başkanlığı (Directorate of Religious Affairs) in the management of Syrian refugees in Bursa, a major industrial and trading centre of 1.8 million in the north-west of the country. It looks at the work of one of the Diyanet's largest and busiest Muftiate offices - particularly its team of vaiz (a role typically translated as "preacher", but, as this paper will show, their social role is actually much wider and more difficult to define). We worked with Professor Mehmet Emin Ay, former Mufti of Bursa, his (female) Vice-Mufti, Sedanur Sezen, and their team of approximately 100 vaiz between 2015 and 2017. We focussed on accessing the six head-vaiz and 20 senior-vaiz who play the largest role in developing the Muftiate's social policy, as well as those officials working in the city's Yavuz Selim, Görsü and Çarşamba neighbourhoods, where the numbers of Syrians are believed to be greatest. Through interviews and workshops, we heard how the presence of the Syrian refugees both affected their work and, inversely, how they attempted to have an impact of the newcomers' lives. These were held in the Turkish language and notes were taken by hand. The workshops were in public spaces, and the interviews were in a mix of public spaces and the offices of the participants. Notes were taken by hand and later typed up. All participants in the research were voluntary and no children or persons considered 'vulnerable' were involved in the research. Contributors seemed keen to be interviewed and did not declare any issues to be off-limits. The research plan was approved by the University of Manchester's ethics committee.

Despite constituting around 4,000 of the Diyanet's 120,000 employees, the literature dealing with the vaiz is miniscule. Only three empirical studies have been carried out to date and all relate specifically to the work of female vaiz (Tütüncü, 2010; Hassan, 2011; Maritato, 2015). There are no English language studies of Bursa's Muftiate and no studies at all of how it relates to the city's burgeoning Syrian minority. More broadly, most wider studies either compare the operational priorities of religious and secular civil society organisations (Ferris, 2005; De Cordier, 2008) or relate to particular scripturally derived ethical ideas in motivating humanitarian action (Abu-Nimer and Kadayifci-Orellana, 2008; Marfleet, 2011). Few, if any, analyses consider the role of the state in funding or directing religious groups that engage in such work. Even attempts at substantiating typologies of faith-based organisations based on wide-ranging literature reviews do not include the public sector (see Ronald Sider and Heidi Rolland Unruh's (2004) or Gerard Clarke's (2006) otherwise comprehensive taxonomies, for instance).

This study is thus quite different from the existing literature, focussing very much on the approach of civil servants. Having located the vaiz's work within Turkey's overall response to the Syrian refugee crisis, this article will firstly trace out the key role Islamic ideas and traditions play in structuring this area of state policy. Contrary to broader trends in the current literature discussed above, we argue that, not only does the primacy of these motivational factors necessitate analysis in their own right, but also that they are not an impediment to approaching social problems generally experienced by refugee communities. In this case, the Islamic values of the vaiz network are, we propose, contributions to, not detractions from, the Turkish public sector's developing policy response. Specifically, our findings suggest that, in Bursa at least, these values play a key role in three important and inter-connected areas - dealing with the tension between integration and multi-culturalism, managing local conflicts and securing access to social support, health and education services. 


\section{Turkey, Refugees and Asylum}

Always traversing trade routes, multiply invaded and periodically ascending to regional dominance, Turkey's peoples have regularly accommodated large numbers of new arrivals. In the Republican era, from the 1920s onwards, the state has tended to encourage the settlement of those it sees as sympathetic to its nation-building project - Pomaks, Tartars, Bosniaks, Circassians and other "outside Turks" (içcuygu, Toktaş and Soner, 2008). Although the original legislation of 1934 which formalised this predilection has been abrogated, Turkey placed stringent geographical limitations to its ratification of the 1951 Geneva Convention and 1967 New York Protocol on the status of refugees. Influenced by NATO's Cold War imperative of receiving émigrés from the communist bloc, these restrict the state's legal commitment to granting applications from Europeans and, at the government's discretion, those it considers to be of Turkish descent (Öner and Genç, 2015: 253-254). For instance, whereas 1.5 million Iranians were permitted to stay temporarily without visas following the fall of the Shah in 1979, around 300,000 Bulgarian citizens deemed to be of Turkish origin were offered the chance of citizenship when they fled from Zhivkov's increasingly repressive regime in 1989 (Gokalp Aras and Mencutek, 2015: 197). The result has been the emergence of a 'two-tiered asylum policy', which has been maintained in more recent legislation passed in 1994 (Law 6169) and 2006 (Law 5543), following the arrival of as many as 500,000 Iraqis in the wake of the 1991 war and 2003 invasion (içcuygu, 2015: 4-5).

Syrians began arriving in Turkey and applying for asylum under these laws in significant numbers from April 2011 onwards. As part of an initial "open-door" policy, the government announced at a UNHCR conference at Geneva in November 2011 that it would offer unobstructed entry without travel documentation and temporary accommodation in camps with neither individual status determination nor forcible return (Ihlamur-Öner, 2013: 202). Assuming that the Assad regime was on the verge of collapse, Foreign Minister Davutoğlu promoted a narrative of brotherhood, referring to refugees as welcome temporary visitors and suggesting that Turkey could easily house up to 100,000 "guests" in newly-built camps along the border (Gokalp Aras and Mencutek, 2015: 202). When this figure was rapidly exceeded and the scale of the displacement became apparent, however, ad hoc access restrictions emerged, culminating in the closure of the border completely in 2015 and the introduction of a visa regime the following year. By then, the government had built more than 20 camps housing over 200,000 people managed by a much-enlarged Disaster and Emergency Management Authority (Afet ve Acil Durum Yönetimi Başkanlığı, AFAD). It was also becoming clear that the Syrian conflict (or more precisely conflicts) was likely to be long-lasting and without a neat conclusion.

Only around ten per cent of Turkey's registered Syrian refugees are resident in these camps, though, and are thus not best served by a relief agency principally mandated to respond to natural disasters. Responding to criticism that 'the government had clearly made no allowance for [such] an eventuality', new legislation on Foreigners and International Protection (Law 6458) was passed in April 2013 (Kirişci, 2014: 16). Article 103 of which established a General Directorate of Migration Management (Göç Idaresi Genel Müdürlüğü) within the Ministry of Interior with overall responsibility for the 2.5 million+ Syrians living across the country (Erder, 
2016: 125). However, while this new administrative structure succeeded in greatly 'expanding Turkey's protective scope towards forced migrants' (Soykan, 2012: 41), it also solidified its twotier regime by identifying non-Europeans as "conditional refugees" who may only be admitted temporarily until they are resettled to a third country (Öner and Genç, 2015: 254). The specific rights of those within this category were subsequently spelt out in the government's Regulation on Temporary Protection issued later the following year. It legally enshrined Syrians' access to the labour market, healthcare and education based on biometric foreigner ID cards, but did so firmly within the narrative of hosting guests (Dağtaş 2017). With only 2,500 work permits being issued to Syrians by 2014, further measures were introduced in January 2016 which attempted to strengthen the formal employment sector by extending minimum wage stipulations, exempting employers from Syrians' health insurance costs and clarifying recruitment procedures (Erder, 2016: 125; Baban, Ilcan and Rygiel, 2017: 51). Conversely, though, it also limited the proportion of refugees salaried within any one workforce, thereby underlining the temporary character of Ankara's protection regime. This perception was further reinforced two months later by the European Union "one-in one-out" agreement which promised to formalise resettlement processes in return for visa-free travel and €3billion towards the \$5.6 billion estimated to have been spent by the Turkish government up until mid-2015 (iççuygu and Millet, 2016: 5; Kirişci and Ferris, 2015: 3).

So, in all, while the Turkish state has responded to the Syrian crisis very robustly (the 2013 legislation was passed with an extremely rare unanimous parliamentary vote and its implementation has been personally overseen by a former Interior Minister and Deputy Prime Minister, Beşir Atalay), it ultimately has not addressed the country's two-tier asylum system. While it remains the key institutional structure governing the social position of its refugees, the extent to which this is likely to stay so, however, is open to some question. As far back as November 2014, Deputy Prime Minister Numan Kurtulmuş conceded that 'the Syrians are here to stay and that the refugees are permanent' (quoted in Memisoglu and Ilgit, 2017: 316). President Erdoğan, whose wife (Emine Gülbaran) is of Arab descent, has also voiced the possibility of Syrians being offered the chance 'to acquire Turkish nationality', telling a 2016 iftar gathering in Kilis that 'Turkey is also your homeland' - plans he repeated in 2017 with the announcement that the Ministry of Interior would shortly be beginning an initial 'screening process' (al-Jazeera, 2016; al-Jazeera 2017).

\section{Syrians, the Diyanet and the AKP}

In mid-2011, there were around 19,000 registered refugees in Turkey, the majority of which came from Iraq, Afghanistan and Iran. Of these, two thirds were of working age (18 to 59 years old). By early-2018, the country is home to the greatest number of refugees in the world, with more than 3.7 million Syrians registered with the authorities (European Commission 2018; (Memisoglu and Ilgit, 2016: 1). While the demographic structure of the former remains broadly unchanged, more than half of Turkey's Syrian refugees are under the age of 19 (more than 360,000 of these have been born in Turkey) (iççuygu, 2016: 11-14). Around one-third are believed to live outside the country's southern and south-eastern provinces. The most popular destinations are Istanbul, Ankara and Konya. The city estimated to have the fourth largest population of Syrians is Bursa, the locus of our study (Erdoğan, M. M., 2014: 14). 
Located in Turkey's wealthy Marmara province and the Ottoman capital from 1335 to 1363 , Bursa has long been a centre of migration. Although far from the Syrian border, it is believed to have received over 50,000 refugees. Most are thought to come from the Aleppo region, with which Bursa has a long history of trade links. It is difficult to be certain about overall numbers, though, as many remain unknown the authorities. The facts that the process of registration with AFAD is convoluted and city-specific, combined with an ongoing fear that, as Baban, Ilcan and Rygiel note, this information could be obtained by the Syrian regime or appear 'in European databases that could lead to their deportation back to Turkey' should they decide to apply for asylum elsewhere (2017: 49), means that the actual total number of Syrians in the city may therefore be much higher than official figures. While many have opened small businesses visible across the city (sometimes as a result of local authorities expediting the usual registration procedures), those only in receipt of informal assistance and/or working in the grey economy are especially difficult to access. As a result, little is known about their lives. Many only come to the attention of statutory bodies when they approach neighbourhood mosques for help. Since all places of worship are managed by the Turkish state, they are typically passed onto officials employed by the Diyanet.

At the city level, this means the Muftiate and its team of vaiz. They have their roots in the creation of the Directorate of Religious Affairs in 1924 following the abolition of the Ottoman waqf foundations (Law 429). Staffed with clerics who had backed the war of independence (others had sided with the incumbent Ottoman government functioning under occupation) and modelled on the post-revolutionary French model of laïcité, it was subsumed within the Ministry of Interior as a kind of Bureau Central des Cultes (Gözaydın, 2008: 218). Initially, its principal modus operandi was to relegate religious practice to the private sphere. Without a pronounced public profile and thus needing few professional staff, it retained large numbers of voluntary roles encompassing a broad range of social functions. As it gradually took up a more political position as protector (or, some would say, imposer) of state religion, these became professionalised by means of the Imam-Hatip school system and then, more recently, closely associated with university education through the parallel development of divinity faculties as the principal replacement of Ottoman religious training structures (Yavuz, 2003: 146).

The vaiz are key functionaries of the republican system. Frequently holding graduate degrees and enjoying high levels of social authority, their role is fourfold: (1) presenting talks ( $\left.v a^{\prime} a z\right)$ on various aspect of Islam within mosques and the community (2) leading educational events and cultural activities associated with Islam - festivals, summer camps, conferences etc (3) offering legal opinions (fatawa) as the Mufti's representative (the most senior female vaiz frequently serves as his deputy) and (4) working with individuals, families and organisations to resolve local conflicts and promote Islamic values. Their overall aim is to elaborate and disseminate a "true" understanding of Islamic knowledge' as defined by, and in the service of, the Turkish state (Maritato, 2015: 438). Their work is thus quite different from the Islamically-inspired NGOs which make up the bulk of studies of welfare and faith in Turkey (such as Göcmen, 2014: 94). Rather, as Mona Hassan notes, the vaiz are a 'pious political agency enmeshed in a deeply complicated and shifting set of power religions between the laic Turkish Republic and its citizens in the active management of religion in Turkish society' (2011: 454). 
Running contrary to a more general picture of state retrenchment and increased markestisation, these efforts have advanced considerably under the AKP (Adalet ve Kalkınma Partisi, Justice and Development Party) government since 2002. Connected to the wider political dynamics that have marked President Erdoğan's leadership - most notably the ongoing tensions between the secular republican establishment and the religious orientation of many AKP voters - the Diyanet has enlarged its profile, responsibilities and resources considerable. Growing from 80,000 to more than 120,000 employees since 2005 and currently managing over 86,000 mosques with a budget of over 3 billion lira, it is now larger than the Ministry of Interior. Under the leadership of Mehmet Görmez from 2010 to 2017, its senior staff started to take on a much higher profile political role, offering forthright moral commentaries on contemporary social issues generally in line with the government's policy preferences (Öztürk, 2016: 626-627). The Syrian crisis has not gone unnoticed. Görmez, who was born in the town of Nizip just 30 kilometres from the Syrian border, frequently visited refugee schools, organised the disbursement of overseas funding (most notably from the Qatari government) and signed an agreement with AFAD placing the Diyanet at the centre of the Turkish state's social response. Perhaps following Erdoğan's lead, he also regularly implied that the Syrian minority will be permanent, telling a social support centre in Ankara that the refugees 'are not guests', that Turkey is their 'own home and country' and that its citizens must host them 'as a human, Muslim and neighbourly duty' (Hürriyet Daily News, 2017).

\section{Islam, Refuge and the Vaiz}

Scholars have put forward multiple ethical reasons for extending assistance to refugees: from security oriented self-interest, to social contract theory, utilitarianism and liberal universalism (Boswell, 2005). The principal finding from our research, though, is that Islamic notions of assistance appear to outweigh other possible motives. The vaiz were unanimous in emphasising the ethical obligations that all Muslims have in assisting refugees, especially if one's neighbours are in difficulty. At the most general level, this is based on a fundamental reciprocity between human beings. The Mufti was keen to point out that the Qur'an principally addresses "people" (insa'an), not just "believers" (mu'minun). Its injunctions are therefore intended both to provide for, and guide the behaviour of, humanity in general - not simply Muslims. A number of vaiz referred to the well-known hadith; 'none of you [truly] believes until he wishes for his brother what he wishes for himself' (translation from Imam Nawawi's collection).

This is, they stressed, 'particularly so in the case of forced migration'. The prophet, himself, was a refugee - obliged to flee persecution in Mecca for the sanctuary of Yathrib (later renamed Medina) in 622. Those that helped him (known as the Ansar) are especially blessed. Then as now, religious orientation is unimportant. The vaiz pointed out that, since Yathrib was a diverse town made up of Jews and pagans (Donner 2002-2003), 'there should be no differentiation between Muslim and non-Muslim Syrians, nor Shi'a and Sunni'. This is, they argued, 'very much in keeping with Turkish tradition'. Sultan Beyazid II offered sanctuary to 150,000 Spanish Jews following the Alhambra Decree of 1492, perhaps as many as 200,000 non-Muslim Russians arrived in the Ottoman capital or its Black Sea cities after the Bolshevik revolution and no-one questioned the confessional identity of the Iranian émigrés of the early 1980s (Lewis, 2014: 135- 
6). The Qur'an itself is clear, the vaiz reminded us - even to the point of assisting one's opponents. The first half of Verse 6, Chapter 9, for example, reads, 'if any of the idolaters ask you for protection, give them protection until they have heard the words of Allah' (Bewley and Bewley, 2013: 172).

To emphasise this universalist message, the vaiz we spoke to mostly preferred to describe the Syrian refugees as muhacir, defined in the Qur'an as "those who make hijra [leave their homes] for Allah's sake after being wronged' (Chapter 16: Verse 41 (Bewley and Bewley, 2013: 253)). This differs from the more common Turkish word, mülteci, in three key ways. Firstly, it is more closely connected to Islamic notions of travel, including the annual pilgrimage to the Hijaz (Lewis, 1988: 106). Secondly, the term is also used to refer to the five million or so migrants who arrived in Anatolia from former Ottoman territories during the last two centuries of the Empire. These included Mustafa Kemal, the founder of the Republic, as well as many others considered to be central to the emergence of the modern Turkish state (Çağaptay, 2006: 82). Thirdly, whereas mülteci involves crossing a border, usually as a result of forced displacement, the muhacir may have simply moved within Muslim lands, perhaps through choice.

The term thus implies a legal or legitimate undertaking which has come to include economic migration (for, as Chapter 62: Verses 9-11 make clear, believers are expected to spread throughout the earth in pursuit of Allah's bounty) (Dündar, 2014: 227). Presenting fewer connotations of need in this way better represents the socio-economic spread of Bursa's Syrians, the vaiz argued. Some, particularly those that left nearer to the start of the civil war, are - they point out - very wealthy and have made substantial investments in the city's economy). It also connects them to longer-term patterns of population movement within a region hitherto dominated by Turkey. One interviewee, noting a long shared heritage, mentioned how Syrians fought alongside Turks in the Gallipoli campaign. Some also used the term göçmen - defined by Pusch and Sirkeci as a reference to 'recent migration movements of people of Turkish descent and culture...[who may have] certain rights for incorporation in Turkey' - as a means of unsettling the two tier asylum structure in which they work (2016: 14).

Indeed, this distinction between those refugees covered by Turkey's conditional ratification of the Geneva convention and those that are not is ignored by the vaiz who prefer, instead, to emphasise the universality of Islamic teachings and its foundational notion of aman, the provision of sanctuary/asylum (al-Dawoody, 2011: 129). Just as Negus, the Christian King of Ethiopia, sheltered a small group of early Muslims around the period of 613-616 (including the future Caliph, Uthman ibn Affan) despite enticement and intimidation, so should the Turkish state continue to welcome Syrians, the vaiz argued, with regard to neither the identity of the migrants nor the resultant strain on public services (Lings, 2006: 81-84). The implication here is that an inviolable principle of non-refoulement should be accompanied with an undifferentiated asylum policy which ensures long-term integration based on the provision of adequate public goods. This would seem to be fullest means of meeting the Qur'anic injunctions to ensure that the muhacir should 'find many places of refuge on the Earth and ample sustenance' as well as 'good lodging in this world' (Chapters 4 (Verse 100) and 16 (Verse 41) respectively (Bewley and Bewley, 2013: 83, 253)). After all, the vaiz concluded, 'those who have given refuge and help', to 
the migrant, are, the Qur'an makes clear 'the true believers' (Chapter 8: Verse 74 (Bewley and Bewley, 2013: 170)).

\section{Transiency, Permanence and Conflict}

In helping to provide "refuge" and "good lodgings", the vaiz have had to balance two powerful concerns. The first is the tension between the need to absorb Syrians into Turkish life while also seeking to preserve their own cultural orientation. As such, the vaiz have concentrated on combining basic assistance initiatives with longer-term efforts aimed at integration. The deployment of a religious discourse to encourage local companies to distribute free bread or worshippers to donate money (single Friday collections at the larger mosques regularly raise in excess of 300,000 Turkish lira (approximately $€ 75,000$ ) they report) has thus operated alongside a successful campaign to pressure the government into issuing foreign guest identification cards that allow Syrians to access community health centres, schools, social services and so on (eventually incorporated into the legislation discussed above). A comparable balance is apparent in the sponsorship of youth events. Joint activities for Turkish and Syrian children and young people remain the preferred policy, but are organised together with an annual nationwide summer camp specifically for young Syrians. Hosted collaboratively by the Youth and Sports Ministries in the town of Kırşehir, it attracted over 400 attendees in 2015 and included vaiz from Bursa who assisted with lessons, prayer leadership and so on.

Similarly, the Muftiate's consistent promotion of the Turkish language (especially to older arrivals who are struggling to pick this up) is thus placed alongside the obligation for all believers to learn Arabic in order to access key religious texts. After all, the vaiz reminded us, the Qur'an solely exists in Arabic and instructs the prophet to speak only 'in a clear Arabic tongue' (Chapter 26: Verse 195 (Bewley and Bewley, 2013: 357)). The implication here is that Turks' inability to communicate with Syrians is thus their own shortcoming. This was perhaps an element in the government's recent announcement that Arabic would be offered to all primary school children nationwide. First suggested in 2011, the vaiz see the proposals as an important element in Turkey's three-year plan to incorporate the 600,000 or so Syrian children still not enrolled within the state school system (International Crisis Group, 2018: 18). Since, at present, the law does not permit the establishment of places of worship outside Diyanet control, this encouragement of Arabic is also seen by the vaiz as a way of bringing congregations together within mosques.

As such, the Mufti reported that he had rejected requests to hold separate prayers (he also said that he feared different forms of Islamic practice might become a source of divisiveness), but had donated a building to the Syrians for their informal use - categorically not a mosque he underlined. Some of the vaiz, however, mentioned that such restrictions may be likely to change in the near-future. The state has, they pointed out, recently recruited around 1,000 mele (Kurdish religious leaders) 'to establish better contact with Kurdish speaking people', thereby effectively permitting Kurdish mosques (Yildiz, 2013: 665), while the Alevi minority's campaign to gain state funding for their places of worship has also been endorsed by deputy AKP leader, Ayhan Sefer Üstün, 'without preconditions' (Yalman, 2016). All the vaiz we spoke to maintained the view that the AKP has been more pluralist in this regard than other parties - in loosening 
restrictions on Islamic practice more generally, they argued, more social space becomes available for cultural expressions of all kinds.

The second key concern structuring the work of the vaiz is balancing the tension between meeting the Syrians' acute social needs and the management of local conflicts. Public opinion surveys in Turkey have regularly recorded comparatively high levels of xenophobia (Erdoğan, E., 2014) and there was a widespread fear amongst the vaiz that Bursa could suffer the kinds of mass protests and violence that have marked cities such as Gaziantep, Adana, Izmir, Manavgat and Reyhanlı (Toğral Koca, 2016: 67). All reported growing tensions and encountering low-level hostility across the municipality. However, perhaps because Bursa has traditionally been a strong supporter of the AKP and its pro-refugee policy position (11 of its 18 parliamentary deputies are currently members of the party), reported incidences of hate crime have been few - even from areas of the city in which the proportion of Syrian refugees is at its highest, such as the satellite town of Gürsu. That said, however, a nationwide survey carried out in October 2014, of which 10 per cent of its respondents came from Bursa, found that more than threequarters agreed with the statement that 'Syrians who stay in Turkey may cause major problems' and only 23 per cent believed that they are not involved in crime (Erdoğan, M. M., 2014: 32-34).

Vaiz working in the predominantly Kurdish neighbourhoods of Bursa's central district of Osmangazi reported the highest numbers of problems. The refugees' arrival in this part of the city coincided with a catastrophic earthquake in the Kurdish city of Van and the emergence of what Memisoglu and Ilgit call a 'rival victim' mentality (2017: 327). When the government began issuing temporary identification cards in time for the local elections of March 2014, the press predicted that full citizenship would follow, thereby 'turning [Syrians] into potential voters' - a concern which intensified when similar reports suggested that refugee camps were being constructed in areas where the AKP had traditionally received little electoral support (Göktuna Yaylacı and Karakuş, 2015). Unease rose higher still later that year during the siege of Kobanî/Ayn al-Arab amid allegations that Ankara was doing little to help the Kurdish militia fighting a predominantly Sunni Arab coalition that might be regarded as difficult to distinguish from the bulk of Syria's émigrés to date (Ihlamur-Öner, 2013: 206). This contributed to the collapse of the intermittent ceasefire between the state and Turkey's principal Kurdish insurgent group (the Partiya Karkerên Kurdistanê, PKK) costing more than 1,700 lives over the next 12 months and increasing tensions nationwide. It also prompted perhaps as many as 500,000 Syrian Kurds to cross the border, complicating the PKK's opposition to the government's resettlement programme and creating a new dimension to the management of inter-communal relations in Turkey's cities (Mandıracı, 2016; Kılıçaslan, 2016).

The vaiz pointed to the localisation of these broader conflict dynamics as both a key policy challenge and a primary cause of neighbourhood opposition within Bursa. Refusing to be drawn on the criticism that Turkey has been able to meet neither international norms nor the terms of its own 1994 and 2006 legislation in separating combatants from civilians within its refugee population (Naftalin and Berg Harpviken, 2012), they maintained that most of the former combatants within Bursa's refugees are 'moderates from the Free Syrian Army'. All agreed, however, that the city is also home to former and current operatives of the Syrian state, as well ex-soldiers from the Islamic State. At the local level, the vaiz have responded to such a 
patchwork of tensions with recourse to traditional Islamic notions of sulh (compromise). Following Chapter 49: Verse 9 of the Qur'an, which states that, 'if two parties of the believers fight, make peace between them', they reported that much of their time is spent 'emphasising toleration, universalism and forgiveness, as well as the advantages of mediation over litigation' (Bewley and Bewley, 2013: 506). After all, one vaiz pointed out, it was Ottoman clerics who first codified Islamic arbitration conventions, through the compilation of the medjella in $1869-\mathrm{a}$ treatise which still influences negotiation practices across the (Hanefi) Muslim world today (Kutty, 2006: 568).

\section{Social Support, Work and Education}

This commitment to tactical conflict management, coupled with a strategic dedication to guiding Turkish society towards an acceptance that its Syrian presence will remain long-term, are the over-arching principles that structure the vaiz's approach to the major policy areas in which they work. In terms of social support, for instance, they have encouraged landlords to provide low-cost housing for refugees, while also dealing with local resentments over resultant rises in rental costs across the city (a nationwide issue blamed on the Syrians (Öner and Genç, 2015: 255)). A similar situation exists in accessing primary and emergency healthcare. Since this is available free for the refugees - many of whom have very complex treatment needs - already overstretched provisions in some parts of the city have suffered, leading to delays for local people and a subsequent increase in antagonism. Recent survey data, for instance, suggest that more than 70 per cent of Turkish citizens regard the refugees as an economic burden (Erdoğan, M. M., 2014: 28). To try to ameliorate these problems, Bursa's vaiz have joined a city-wide association of more than 60 local NGOs operating together - despite widely differing approaches to the public place of religion, local issues and party politics. Supervised jointly by the Mufti, the provincial governor and the city council, the aim, they told us, is 'to offer a more joined-up approach to the practical difficulties of immigrant life, while also promoting closer inter-communal relations'.

A growing element of these interactions, the Mufti suggested, is matrimony. All the Diyanet employees we spoke to agreed that marrying local people is an especially enduring means of integrating the refugees. They pointed to three main benefits here; (1) "grounding" the large numbers of young Syrian men within Turkish familial convention (2) protecting vulnerable unaccompanied Syrian women and providing an additional parent for their children and (3) lessening local prejudice, particularly perceptions that Syrians are involved in theft and prostitution. However, some of the female vaiz pointed out that Syrian women's reputation for beauty and domestic management have prompted issues of jealousy, as well as infidelity and increases in divorce rates (Orhan and Senyücel Gündoğar, 2015: 16). Significant, here, is the legacy of the "natasha" discourse of the 1990s when migrant women from the former Soviet Union became associated with prostitution, leading to a widespread harassment and even violence - sometimes from Turkish women (Gülçür and Iilkkaracan, 2002: 414). According to Bruce Stanley, Bursa remains an important trading post in the illegal trafficking of Eastern European women (2007: 103). This has added to anti-Syrian prejudice, especially where some Turkish men have married Syrians polygamously, occasionally seeking to justify their actions on the grounds of Islam or humanitarianism. There have also been reports that some of those 
involved have been underage or coerced (see Kirişci, 2014: 29, for instance), but the vaiz knew of no cases locally and, as M. Murat Erdoğan observes, the number of officially confirmed incidents has tended to be very low (2014: 21).

Working at a very local level, the vaiz have responded to these issues by developing highly sensitive conflict management approaches based on a combination of faith references and pragmatism. Firstly, they have emphasised that polygamy in Turkey (unlike in Syria) is illegal and, secondly, they have underlined that, in order for a marriage to be legitimate Islamically, it must be entered into freely - necessitating, in other words, independent volition, informed consent and mental capacity (none of which is applicable to a child). In an effort to diminish this kind of in camera arrangement, Muftiate staff have also used their ex officio influence to circumvent some of the state's normal procedures regarding statements of no impediment, birth certificates etcetera and to register weddings for couples unable to provide the usual documentation.

The vaiz have also campaigned hard to find Bursa's refugees jobs and to bring those already working into the formal sector. Unemployment is a major issue for Syrians across the whole country, with the provinces in which they predominantly reside experiencing rates of joblessness at double the national average of 10 per cent. Their presence within the unregistered employment sector has also helped to increase this area of the labour market to around 32 per cent of the workforce (iççuygu, 2016: 9-10). In Bursa, the vaiz reported some success in assisting refugees into work. A reputation for excellence in joinery has allowed some to access Bursa's furniture factories, while Diyanet officials have advised many others on how to register small businesses with local chambers of commerce. Significant problems of Turkish literacy and qualification accreditation remain, however, frequently obliging the Syrians to work for a fraction of the minimum wage (Sert, 2016: 108). As Kemal Kirişci notes, those 'willing to take lower wages and work longer hours face a higher risk of exploitation with little recourse while provoking resentment among locals' (2014: 22). While the vaiz reported that some of Bursa's local businesses have benefited from cheap labour - especially to do the so-called "3D" jobs (dirty, dangerous and difficult) of the construction, textile and agricultural sectors - they remain worried about exploitation and have regularly reported suspicions to the regulatory authorities (who, in keeping with a nationwide rise in enforcement, have imposed heavy fines for breaches of the law (Baban, Ilcan and Rygiel, 2017: 52)). This is important, they argued, if, firstly, the general feeling that Syrians are 'taking away or stealing jobs... [by] establishing taxfree businesses and depressing wages' is to be redressed (Toğral Koca, 2016: 68) and, secondly, if the right to work is to be extended (nearly half of respondents to a nationwide survey in 2014 held the view that work permits should never be granted to refugees (Erdoğan, M. M., 2014: 30)).

Of particular concern to the vaiz is the fact that Bursa's grey economy includes a growing number of working children - a feature already 'common in Turkey among migrant workers' (Şenses, 2016: 981). Data recently released reveal that less than half of the country's registered refugee children of school-age are enrolled in education, even though the right to receive this free of charge is specifically written into Turkish law, leading UNICEF to warn of an imminent 
"lost generation" (İçduygu, 2016: 25; Kirişci, 2014: 23). In Bursa, the Syrian community has responded by establishing their own Arabic-medium schools, taking advantage of European Union harmonisation legislation (principally directed at the country's Kurdish language speakers) which permits education in minority languages. At the time of our research, there were around 30 of these operating in Bursa. Most are small and informal, but three - Risalet, Fecr Ikra and Mühabbet - are relatively large with several hundred pupils in each. A full curriculum is taught with a particular emphasis on Turkish language. The objective is to gain entry into the mainstream education system, with many students going on to Imam-Hatip schools. Mainly serving the estimated 4,000 or so Syrian children not enrolled at one of Bursa's state schools, they are registered as NGOs and co-operate closely with similar establishments in Reyhanlı, Gaziantep, Kilis, Mersin and Istanbul.

Unlike in these other cities, though, Bursa's former provincial governor, Münir Karaloğlu, refused to grant official status to Syrian schools, preferring instead to promote the merits of combined education. Arriving in post at the height of the displacement crisis in 2013, he was, perhaps, responding to public unease over curriculum-content and gender-segregation within the schools. As Kemal Kirişci notes, 'content and delivery is vulnerable to politicization due to resentment, prejudice, and sectarianism triggered by the war in Syria'. We saw no evidence of this in the schools we visited in Bursa and it might be possible that Karaloğlu was concerned that validating Arabic-medium establishments would raise what Kirişci calls 'accusations of doublestandards' over the ongoing difficulties that Kurds have had in sustaining minority language provisions - all five Kurmanci-medium primary schools set up since deregulation have now closed amid an acute deterioration of security in the south-east of the country (2014: 25). As a result, Bursa's Syrian schools cannot host public exams, are forced to seek funding from overseas (notably the Bahraini humanitarian organisation, Jasad Wahed) and must send their students to be assessed in Istanbul.

Opinion within the vaiz appeared to be divided on the issue of separate or combined education. Some worried about the long-term social effects of offering official recognition to Syrian schools, while others pointed to the more acute practical difficulty of including (especially older) refugee children in mainstream classes that they cannot understand. All were agreed, however, that greater levels of public funding will need to be allocated to the state-school system in order to incorporate refugee children long-term, without increasing class sizes or lessening academic attainment (already important concerns amongst local people) (Orhan and Senyücel Gündoğar, 2015: 35).

The Muftiate has attempted to deal with this unease by emphasising the centrality of education to Islamic thought and action. The first word of the Qur'an, the vaiz reminded us, is not "believe" or "obey", but "read/proclaim" (ikra). It then goes on to mention the value of learning 865 times, making clear, for instance, that only those 'with knowledge have fear of Allah' (Chapter 35: Verse 28) (Bewley and Bewley, 2013: 422; Saiful Islam, 2016: 6). In practical terms, the vaiz have also organised the establishment of Arabic medium courses combining religious education with intensive Turkish language instruction, utilising Bursa's bi-lingual communities from Turkey's southern cities. Using their Arabic language skills (a common - but as yet not entirely universal - aspect of university divinity programmes), the vaiz have interviewed 
voluntary teachers and supported them with training as more and more Syrian nationals take up employment within the Diyanet's Qur'anic education sector. The appointment process focussed on fairly standard aspects of religious knowledge, but included subtle questions designed to uncover the types of politicisation described by Kirişci above. None had been found at the time of the research, but if discovered, it would, the vaiz reported, be a criterion for rejection.

\section{Conclusion}

This article can be read as part of wider reflections on the meanings and ownership of humanitarianism. The sector is under-going rapid and far-reaching change, and the case of the vaiz - and many other actors in other contexts - necessitate a rethinking of humanitarian space. In relation to our case study, that space is occupied by the state, a religious organisation and a religious belief system all encompassed in one body. Our case study encourages a thinking through of the heterogeneity of charitable actors, and the implications this has for the meanings and direction of humanitarianism.

In particular, there is, as Alastair and Joey Ager have recently pointed out, a general 'invisibility' of local faith organisations within studies of how host communities engage with displaced people. They call for 'an attempt to re-envision the[ir] role... [as] core to the understanding of refugee experience and support' (2017). This study has tried to do just that. It has looked at the almost completely ignored contribution of the vaiz to the management of Turkey's Syrian population in one the country's largest cities. Following Ager and Ager's three-part call for greater recognition, it has focussed firstly on how the vaiz sought to establish relationships with the refugees through a shared understanding of Islamic values and narratives. While our study only concerned Muftiate employees and therefore did not assess how their work was received by the Syrians themselves, it is certainly possible to conclude that, for the former, building connections with Bursa's refugee population is - as Ager and Ager suggest - not simply about developing coping strategies based on a shared identity, but also a profoundly spiritual experience. In all, what is surprising and revealing here is not that vaiz's work is embedded in Islamic values - after all, relations between people either side of what is now the Turkish-Syrian border have been heavily influenced by religious thought and institutions for many centuries but that their role within the Turkish state's response to the refugee crisis has received so little attention.

The vaiz have, we argue, also mobilised what Ager and Ager call 'spiritual capital' in the development of hospitality as a moral imperative - the second part of their call to re-envision the role of faith in humanitarian response. 'Far more than the provision of resources relevant to a predetermined agenda of refugee reception', the Diyanet's narrative of "welcoming the stranger" has placed Islamic notions of cordiality at the heart of Turkey's role as a regional host (Ager and Ager, 2017: 49). Taking a lead from President Erdoğan, who has called upon his citizens to 'serve as ansar to the muhajirun... [and] open their houses exactly like it happened at the time [of the prophet]', the vaiz have focussed extensively on the Islamic responsibility to offer assistance to those in need (quoted in Hürriyet Daily News 2016). Facing comparable challenges to any other ("secular") agency, they have, we suggest, balanced the need to absorb 
Syrians into Turkish life while also seeking to resolve related local conflicts by deploying religious teachings that advocate values not dissimilar to those of international humanitarian norms.

In doing so, the vaiz have also embraced 'a third key role for local faith communities: advocacy for the displaced and challenge of governmental policies that fail to respect their shared humanity' (Ager and Ager 2017: 50). Their emphasis on the universal moral imperative of offering sanctuary disputes Turkey's two-tier asylum system and its premise of temporariness or what, in cultural terms, Seçil Dağtaş has recently called the misafir (guest) narrative (2017). Concurring with Ager and Ager's conclusion that religion is 'one of the most powerful potential sources of [such] critique' (2017: 50), our interviewees were unanimous in asserting the refugees' right to permanent residence. They see their role as, in part, preparing Turkish society to accept the fact that many will never return. Although circumscribed by their position as public sector officials, Bursa's vaiz have, as such, aimed to fill the (frequently extremely wide) gaps in the state's response. Using its command of scriptural sources, its social status and its exceptional ability to reach into Turkish society, the Muftiate has, we argue, constructed sophisticated religious narratives aimed at realised a wide-range of policy objectives. These have not only been focussed on the universal concerns of humanitarian intervention - housing, employment and education - but also on gender relations and spiritual welfare.

\section{References}

Abu-Nimer, M. and Kadayifci-Orellana, S. A. (2008) Muslim peace building actors in Africa and the Balkan context: challenges and needs. Peace \& Change 33(4): 549-581.

Ager, A. (2014) Faith and the secular: tensions in realising humanitarian principles. Forced Migration Review 48: 16-18.

Ager, A. and Ager, J. (2011) Faith and the discourse of secular humanitarianism. Journal of Refugee Studies 24(3): 456-471.

Ager, A. and Ager, J. (2015) Faith, Secularism, and Humanitarian Engagement: Finding the Place of Religion in the Support of Displaced Communities. New York: Palgrave Macmillan.

Ager, A. and Ager, J. (2017) Challenging the discourse on religion, secularism and displacement. In: L. Mavelli and E. K. Wilson (eds) The Refugee Crisis and Religion: Secularism, Security and Hospitality in Question. Lanham MD: Rowman and Littlefield, pp. 37-52.

al-Jazeera (2016) Erdogan: Syrian refugees could become Turkish citizens, 3 July. http://www.aljazeera.com/news/2016/07/erdogan-syrian-refugees-turkish-citizens160703133739430.html.

al-Jazeera (2017) Erdogan offers citizenship to Syrian and Iraqi refugees, 7 January. http://www.aljazeera.com/news/2017/01/erdogan-offers-citizenship-syrian-iraqi-refugees170106195134961.html. 
Baban, F., Ilcan, S. and Rygiel, K. (2017) Syrian refugees in Turkey: pathways to precarity, differential inclusion, and negotiated citizenship rights. Journal of Ethnic and Migration Studies 43(1): 41-57.

Bewley, A. and Bewley A. (2013) The Noble Qur'an: A New Rendering of its Meaning in English. London: Ta-Ha Publishers.

Boswell, C. (2005) The Ethics of Refugee Policy. Aldershot: Ashgate.

Çağaptay, S. (2006) Islam, Secularism, and Nationalism in Modern Turkey: Who is a Turk? Abingdon: Routledge.

Clarke, G. (2006) Faith matters: faith-based organisations, civil society and international development. Journal of International Development 18(6): 835-848.

Dağtaş, S. (2017) Whose misafirs? Negotiating difference along the Turkish-Syrian border. International Journal of Middle East Studies 49(4): 661-679.

al-Dawoody, A. (2011) Islamic Law of War: Justifications and Regulations Basingstoke: Palgrave Macmillan.

De Cordier, B. (2008) The "humanitarian frontline", development and relief, and religion: what context, which threats and which opportunities? Conflict Research Group Working Paper 10(July).

Donner, F. (2002-2003) From believers to Muslims: confessional self-identity in the early Islamic community. Al-Abhath 50-51: 9-53.

Dündar, F. (2015) ittihat ve Terakki'nin Müslümanları İskân Politikası, 1913-1918. Istanbul: Iletişim.

Erder, S. (2016) Preliminary thoughts on the Syrian refugee movement. New Perspectives on Turkey 54(May): 119-130.

Erdoğan, E. (2014) Unwanted, Unwelcome: Anti-Immigration Attitudes in Turkey. Washington DC: German Marshall Fund of the United State.

Erdoğan, M. M. (2014) Syrians in Turkey: Social Acceptance and Integration Research. Ankara: Hacettepe University Migration and Politics Research Centre.

European Commission (2018) European Civil Protection and Humanitarian Aid Operations. Brussels.

Ferris, E. (2005) Faith-based and secular humanitarian organizations. International Review of the Red Cross 87(858): 311-325. 
Göçmen, I (2014) Religion, politics and social assistance in Turkey: the rise of religiously motivated associations. Journal of European Social Policy 24(1): 92-103.

Gokalp Aras, N. E. and Mencutek, Z. S. (2015) The international migration and a foreign policy nexus: the case of Syrian refugee crisis and Turkey [sic]. Migration Letters 12(3): 193-208.

Göktuna Yaylacı, F. and Karakuş, M. (2015) Perceptions and newspaper coverage of Syrian refugees in Turkey. Migration Letters 12(3): 238-250.

Gözaydın, I. B. (2008) Diyanet and politics. The Muslim World 98(April/July): 216-227.

Gülçür, L. and ilkkaracan, P. (2002) The "Natasha" experience: migrant sex workers from the former Soviet Union and Eastern Europe in Turkey. Women's Studies International Forum 25(4): 411-421.

Hassan, M. (2011) Women preaching for the secular state: official female preachers (bayan vaizler) in contemporary Turkey. International Journal of Middle East Studies 43(3): 451-473.

Holenstein, A-M. (2006) Governmental donor agencies and faith-based organizations. International Review of the Red Cross 87(858): 367-373.

Hürriyet Daily News (2016) Turkish PM calls on Reyhanlı locals to resist 'provocations'. May 24. http://www.hurriyetdailynews.com/turkish-pm-calls-on-reyhanli-locals-to-resist-provocations$\underline{47526 .}$.

Hürriyet Daily News (2017) This land is your land, Turkish religious authority tells Syrian refugees. March 2. http://www.hurriyetdailynews.com/this-land-is-your-land-turkish-religiousauthority-tells-syrian-refugees-.aspx?pagelD=238\&nID=110369\&NewsCatID=341.

İçduygu, A. (2015) Syrian Refugees in Turkey: The Long Road Ahead. Washington DC: Migration Policy Institute.

Içcluygu, A. (2016) Turkey: Labour Market Integration and Social Inclusion of Refugees. Brussels: European Parliament Directorate General for Internal Policies.

İçduygu, A. and Millet, E. (2016) Syrian refugees in Turkey: insecure lives in an environment of pseudo-integration. Global Turkey in Europe Working Paper 13.

İçduygu, A., Toktaş, ş. and Soner, A. (2008) The politics of population in a nation-building process: emigration of non-Muslims from Turkey. Ethnic and Racial Studies 31(2): 358-389.

Ihlamur-Öner, S. G. (2013) Turkey's refugee regime stretched to the limit? The case of the Iraqi and Syrian refugee flows. Perceptions 28(3): 192-228. 
International Crisis Group (2018) Turkey's Syrian Refugees: Defusing Metropolitan Tensions. Brussels.

Kidwai, S. (2017) The limits of hospitality: finding space for faith. In: L. Mavelli and E. K. Wilson (eds) The Refugee Crisis and Religion: Secularism, Security and Hospitality in Question. Lanham MD: Rowman and Littlefield, pp.175-186.

Kılıçaslan, G. (2016) Forced migration, citizenship, and space: the case of Syrian Kurdish refugees in Istanbul. New Perspectives on Turkey 54(May): 77-95.

Kirişci, K. (2014) Syrian Refugees and Turkey's Challenges: Going beyond Hospitality. Washington DC: Brookings.

Kirişci, K. and Ferris, E. (2015) Not likely to go home: Syrian refuges and the challenges to Turkey - and the international community. Brookings Turkey Project Policy Paper 7 (September).

Kutty, F. (2006) The shari'a factor in international commercial arbitration. Loyola of Los Angeles International and Comparative Law Review 28(3/4): 565-624.

Lewis, B. (1988) The Political Language of Islam. Chicago: University Of Chicago Press.

Lewis, B. (2014) The Jews of Islam, Princeton, NJ: Princeton University Press.

Lings, M. (2006) Muhammad: His Life Based on the Earliest Sources. Rochester, VT: Inner Traditions.

Mandıracı, B. (2016) Turkey's PKK Conflict: The Death Toll. Brussels: International Crisis Group.

Marfleet, P. (2011) Understanding "sanctuary": faith and traditions of asylum. Journal of Refugee Studies 24(3): 440-455.

Maritato, C. (2015) Performing irşad: female preachers' (vaizeler's) religious assistance within the framework of the Turkish state. Turkish Studies 16(3): 433-447.

Mavelli, L. and Petito, F. (2012) The postsecular in international relations: an overview. Review of International Studies 38(5): 931-942.

Memisoglu, F. and Ilgit, A. (2017) Syrian refugees in Turkey: multifaceted challenges, diverse players and ambiguous policies. Mediterranean Politics 22(3): 317-338.

Naftalin, M. and Berg Harpviken, K. (2012) Rebels and Refugees: Syrians in Southern Turkey. Oslo: PRIO Policy Brief.

Öner, N. A. S. and Genç, D. (2015) Vulnerability leading to mobility: Syrians' exodus from Turkey. Migration Letters 12(3): 251-262. 
Orhan, O. and Senyücel Gündoğar, S. (2015) Effects of the Syrian refugees on Turkey. Orsam Report 195(January).

Öztürk, A. E. (2016) Turkey's Diyanet under AKP rule: from protector to imposer of state ideology? Southeast European and Black Sea Studies 16(4): 619-635.

Perna, L. (2006) The Formation of the Treaty Law of Non-International Armed Conflicts. Leiden: Brill.

Pusch, B. And Sikeci, I. (2016) Turkish Migration Policy at a Glance. In: I. Sirkeci and B. Pusch (eds.) Turkish Migration Policy. London: Transnational Press, pp. 9-22.

Saiful Islam, M. (2016) Importance of girls' education as right: a legal study from Islamic approach [sic]. Beijing Law Review 7(1): 1-11.

Şenses, N. (2016) Rethinking migration in the context of precarity: the case of Turkey. Critical Sociology 42(7-8): 975-987.

Sert, D. Ş. (2016) From skilled translation to devaluation: the de-qualification of migrants in Turkey. New Perspectives on Turkey 54(May): 97-117.

Sider, R. and Rolland Unruh, H. (2004) Typology of religious characteristics of social service and education organizations and programs. Non-Profit and Voluntary Sector Quarterly 33(1): 109134.

Soykan, C. (2012) The new draft law on foreigners and international protection in Turkey. Oxford Monitor of Forced Migration 2(2): 38-47.

Stanley, B. (2007) Bursa. In: M. Dumper and B. Stanley (eds) Cities of the Middle East and North Africa: A Historical Encylopedia. Santa Barbara: ABC Clio, pp. 100-104.

Toğral Koca, B. (2016) Syrian refugees in Turkey: from "guests" to "enemies"? New Perspectives on Turkey 54(May): 55-75.

Tütüncü, F. (2010) The women preachers of the secular state: the politics of preaching at the intersection of gender, ethnicity and sovereignty in Turkey. Middle East Studies 46(4): 595-614.

Wilson, E. K. and Mavelli, L. (2017) The refugee crisis and religion: beyond conceptual and physical boundaries. In: L. Mavelli and E. K. Wilson (eds) The Refugee Crisis and Religion: Secularism, Security and Hospitality in Question. Lanham MD: Rowman and Littlefield, pp. 1-22.

Yavuz, M. H. (2003) Islamic Political Identity in Turkey. Oxford: Oxford University Press. 
Yildiz, A. (2013) Turkey. In: J. Nielsen, S. Akgönül, A. Alibašić and E. Racius (eds) Yearbook of Muslims in Europe, Volume 5. Leiden: Brill, pp. 649-668.

Yalman, A. (2016) Can Turkey deliver a landmark religious reform for the Alevi community? Middle East Eye. January 18. http://www.middleeasteye.net/columns/can-turkey-deliverlandmark-religious-reform-alevi-community-1266443921. 